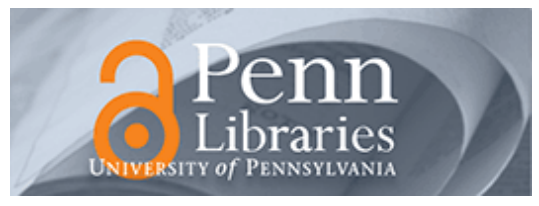

University of Pennsylvania ScholarlyCommons

$10-2008$

\title{
Financial Reporting and Conflicting Managerial Incentives: The Case of Management Buyouts
}

Paul E. Fischer

University of Pennsylvania

Henock Louis

Follow this and additional works at: https://repository.upenn.edu/accounting_papers

Part of the Accounting Commons, and the Business Administration, Management, and Operations Commons

\section{Recommended Citation}

Fischer, P. E., \& Louis, H. (2008). Financial Reporting and Conflicting Managerial Incentives: The Case of Management Buyouts. Management Science, 54 (10), 1700-1714. http://dx.doi.org/10.1287/ mnsc. 1080.0895 


\title{
Financial Reporting and Conflicting Managerial Incentives: The Case of Management Buyouts
}

\author{
Abstract \\ We analyze the effect of external financing concerns on managers' financial reporting behavior prior to \\ management buyouts (MBOs). Prior studies hypothesize that managers intending to undertake an MBO \\ have an incentive to manage earnings downward to reduce the purchase price. We hypothesize that \\ managers also face a conflicting reporting incentive associated with their efforts to obtain external \\ financing for the MBO and to lower their financing cost. Consistent with our hypothesis, we find that \\ managers who rely the most on external funds to finance their MBOs tend to report less negative \\ abnormal accrual prior to the MBOs. In addition, the relation between external financing and abnormal \\ accruals is tempered when there are more fixed assets that can serve as collateral for debt financing.

\section{Keywords} \\ MBO, earnings management, debt financing, managerial incentives

\section{Disciplines} \\ Accounting | Business Administration, Management, and Operations
}




\title{
Financial reporting and conflicting managerial incentives: The case of management buyouts
}

\author{
Paul E. Fischer \\ Smeal College of Business, Accounting Department, Pennsylvania State University, 339 Business \\ Building University Park, PA 16802, email: pef5@psu.edu \\ Henock Louis \\ Smeal College of Business, Accounting Department, Pennsylvania State University, 319 Business \\ Building, University Park, PA 16802, email: hul4@psu.edu
}

We analyze the effect of external financing concerns on managers' financial reporting behavior prior to management buyouts (MBOs). Prior studies hypothesize that managers intending to undertake an $\mathrm{MBO}$ have an incentive to manage earnings downward to reduce the purchase price. We hypothesize that managers also face a conflicting reporting incentive associated with their efforts to obtain external financing for the MBO and to lower their financing cost. Consistent with our hypothesis, we find that managers who rely the most on external funds to finance their MBOs tend to report less negative abnormal accruals prior to the MBOs. In addition, the relation between external financing and abnormal accruals is tempered when there are more fixed assets that can serve as collateral for debt financing.

Keywords: MBO, earnings management, debt financing, managerial incentives

\section{Introduction}

Prior studies suggest that firms manage earnings prior to corporate events such as: MBOs (Perry and Williams 1994), seasoned public offerings (Teoh, Welch, and Wong 1998; Shivakumar 2000), stockfor-stock mergers (Erickson and Wang 1999; Louis 2004), reverse leverage buyouts (Chou, Gombola, and Liu 2006), open-market repurchases (Gong, Louis, and Sun 2008), and Dutch-auction tender offers (Louis and White 2007). These studies generally focus on managers' incentives to use reporting discretion to influence equity market investors. There is little consideration in the literature, however, to the presence of reporting incentives that conflict with the incentives to influence equity market investors. 
We analyze the effect of external financing considerations on managers' financial reporting behavior prior to management buyouts (MBOs). Our interest in MBOs is heightened by the resurgence in MBO activities starting with the late 1990s and managers' renewed interest in MBOs due partly to the desire to avoid the compliance costs associated with the Sarbanes-Oxley Act (Engel, Hayes, and Wang 2007). We are also interested in the MBO setting because extant studies on earnings management prior to MBOs yield mixed results. DeAngelo (1986) finds no evidence of earnings management prior to MBOs whereas Perry and Williams (1994) report evidence consistent with downward earnings management. By controlling for external financing incentives, we may be able to provide clearer evidence that managers respond to equity market incentives. Nonetheless, our main motivation for choosing the MBO setting is the potential conflicting financial reporting incentive associated with external financing considerations.

Managers planning to undertake an MBO want to purchase their firms' equity at as low a price as possible. Consequently, previous studies hypothesize that managers have an incentive to release less favorable earnings reports to equity market participants prior to an $\mathrm{MBO}$ in an attempt to reduce the $\mathrm{MBO}$ purchase price (e.g., Perry and Williams 1994). We consider the possibility that managers have a conflicting earnings management incentive prior to MBOs that is attributable to external financing concerns, which are thought to be substantial (see, e.g., Osborn 1984; Kosman 1998; Tran 2000). In the framework we employ for our analysis, the financing related reporting incentive is driven by management's concerns regarding their ability to obtain MBO financing from external parties and their desire to obtain that financing at a favorable cost. The financing incentive conflicts with the equity market incentive because the financing incentive suggests that managers should manage earnings upward. Consequently, to the extent that an external financing incentive exists, we expect it to temper the equity market incentive. Based upon our framework, we hypothesize that financing related earnings management incentives are more pronounced when the funds needed to execute the buyout must be raised to a greater extent from external parties. In addition, we hypothesize that the increase in financing related incentives arising from increased external financing is greater when there are fewer fixed assets available to secure loans. We find evidence consistent with both hypotheses. 
The remainder of the study is organized as follows. Section 2 provides background information on financing of MBOs. Section 3 discusses managers' conflicting reporting incentives prior to MBOs and formulates our hypotheses. Section 4 describes our earnings management proxy. Section 5 describes the sample selection process and presents some descriptive statistics. Section 6 reports univariate results on earnings management prior to MBOs and the correlation between earnings management and the source of the MBO financing. Section 7 reports multivariate regression results on the association between earnings management and external financing. The study concludes in Section 8.

\section{Financing of management buyouts}

Management buyouts are a form of leveraged buyout in which the management team is part of the investment group buying the firm. Other members of the investment group may be a buyout specialist or an investment bank. The investment group may finance the transaction through internal sources. In most cases, however, MBO firms obtain additional financing from external sources by leveraging the company's assets through secured bank loans that may be syndicated. In addition, further external debt financing may be attained through private placements of subordinated claims with institutions such as pension funds, insurance companies, or venture capital firms or through public offerings of "high yield" or "junk" bonds. After raising the cash required to implement the buyout, the investment group purchases the firm via a merger or a tender offer. See Weston, Chung, and Siu (1997, pp. 316-343) for more details.

While MBOs are generally financed through debt from external sources, internal financing can be substantial. According to statistics from Portfolio Management Data, the percentage of equity invested by buyout firms was 31.6\% in 1998 and 37\% in 1999 (Tran 2000). In fact, some MBOs are financed entirely through internal funds. For instance, Ecometry Corporation states in its Schedule 14A filing with the Securities and Exchange Commission (SEC): "The total amount of cash required to consummate the SG Merger is estimated to be approximately $\$ 23$ million, all of which will be paid by the surviving corporation from the cash that we currently have on hand." As another example, PartsBase states in its filing: "The Acquisition Group, through the cash reserves of PRTS which will become available immediately upon the effectiveness of the merger, has sufficient funds available to pay the merger 
consideration and pay its portion of the fees and expenses incurred in connection with the merger. The merger is not conditioned on any financing arrangements." In summary, there appears to be some significant variation in the funding sources for MBOs, which is critical for our analysis.

\section{Conflicting reporting incentives prior to management buyouts}

Extant literature on earnings management suggests that managers have incentives to manage earnings downward prior to a buyout in order to reduce the purchase price (see, for example, DeAngelo 1986; and Perry and Williams 1994). We argue that external financing concerns could mitigate, but not necessarily dominate, these incentives to manage earnings downward. As has been discussed in prior studies, the economic rents arising from MBOs can be quite substantial. ${ }^{1}$ While MBOs can provide ample benefits to the buyout group, securing the debt financing to execute them is often difficult (see Osborn 1984; Nelson 1985; Buccino 1989; Kosman 1998; and Tran 2000). Thus, at the margin, managers could be dissuaded from managing earnings down to secure a lower equity purchase price, which increases economic rents, because it could jeopardize their ability to obtain the financing needed to capture those rents and adversely alter the terms at which the financing is obtained. Hence, on average, managers who rely the most on external sources of financing are likely to deflate earnings prior to MBOs to a lesser extent than those who rely the most on internal sources of financing.

\subsection{Illustrative model}

To further develop our intuition, we analyze a stylized equilibrium model of financial reporting prior to an $\mathrm{MBO}$ where we assume the manager's objective is to manage earnings to minimize total costs, which have three components: the MBO purchase price, the incremental cost of external financing for the $\mathrm{MBO}$, and the reporting cost. Consider a setting where a manager, who anticipates an MBO, prepares an

\footnotetext{
${ }^{1}$ These benefits include: tax benefits (Kaplan 1989); mitigation of agency costs (Jensen, 1986), stronger managerial incentives under private ownership (DeAngelo et al. 1984); savings of registration, listing, and shareholder servicing costs (DeAngelo et al. 1984); expropriation of bondholders (Masulis 1980); and avoidance of compliance costs associated with the Sarbanes-Oxley Act of 2002 (Engel, Hayes, and Wang 2007).
} 
earnings report, $r$, for his firm. The manager can engage in earnings management that is not observed by external parties so the report satisfies $r=e+m$, where e is unmanaged earnings and $m$ is the level of earnings management (i.e., $\mathrm{m}>0$ is upward earnings management and $\mathrm{m}<0$ is downward earnings management). If the manager engages in earnings management, he expects to incur some legal or regulatory costs equal to $\frac{\lambda_{\mathrm{r}}}{2} \mathrm{~m}^{2}$, where $\lambda_{\mathrm{r}}>0$. Consistent with prior earnings management studies, we use a quadratic cost function because it permits a simple closed-form equilibrium characterization of the manager's earnings management strategy (See Fischer and Verrecchia 2000; or Dye and Sridhar 2004).

To execute the MBO, the manager must have funds to purchase the equity he does not already own and pay for existing senior claims that must be settled. Let $\mathrm{P}$ be the funds required to execute the MBO. We assume $\mathrm{P}=\alpha+\lambda_{\mathrm{e}}\left(\mathrm{r}-\hat{\mathrm{m}}_{\mathrm{e}}\right)$, where $\alpha>0$ represents the payment required to settle senior claims plus any intercept term in a linear pricing function for outstanding equity, $\lambda_{\mathrm{e}}$ represents the sensitivity of the equity market price to equity market participant beliefs about unmanaged earnings, $\lambda_{e}>0$, and $\hat{m}_{e}$ is the equity market participants' beliefs about the manager's earnings management choice. Hence, the linear function captures the idea that the equity price is an increasing linear function of the market beliefs about unmanaged earnings, which are increasing in the report and decreasing in the market beliefs about the manager's earnings management.

The manager expects to raise $\mathrm{f} \geq 0$ funds from external sources, with the remaining funds coming from the MBO group, which includes the manager. The incremental cost of the externally raised funds is a decreasing function of the manager's earnings report, where the sensitivity of the cost to the earnings report is decreasing in the level of the target firm's fixed assets, a, that can be employed as collateral. Formally, the incremental cost per unit of the external financing, $R$, is $\left[\alpha_{f}-\lambda_{f}(a)\left(r-\hat{m}_{f}\right)\right]$, where $\alpha_{f}>0$, $\lambda_{\mathrm{f}}(\mathrm{a})>0, \lambda_{\mathrm{f}}^{\prime}(\mathrm{a})<0$, and $\hat{\mathrm{m}}_{\mathrm{f}}$ is the external financing market beliefs about the extent of earnings management. This function implies that the manager can obtain financing at more favorable rates if the external financiers believe economic earnings are higher. We assume that the external financing cost is 
less sensitive to beliefs about economic earnings when there are more fixed assets to serve as collateral because the additional collateral makes the financiers' debt claims less reliant on future earnings flows for payment. Given the structure of the model, the manager's reporting objective is to choose $\mathrm{m}$ to minimize the cost function

$$
\mathrm{P}+\mathrm{Rf}+\frac{\lambda_{\mathrm{r}}}{2} \mathrm{~m}^{2}=\left[\alpha+\lambda_{\mathrm{e}}\left(\mathrm{r}-\hat{\mathrm{m}}_{\mathrm{e}}\right)\right]+\left[\alpha_{\mathrm{f}}-\lambda_{\mathrm{f}}(\mathrm{a})\left(\mathrm{r}-\hat{\mathrm{m}}_{\mathrm{f}}\right)\right] \mathrm{f}+\frac{\lambda_{\mathrm{r}}}{2} \mathrm{~m}^{2}
$$

As an aside, we should note that our model specification does not explicitly include a notion of credit rationing, which is often referred to as a barrier for executing an MBO. We could implicitly build this notion into the manager's objective function by assuming that the incremental cost of external financing can be so large as to make the MBO infeasible.

A crucial assumption required for the development of our hypothesis is that the manager believes that neither the equity market participants nor the external financiers observe his actual earnings management choice. Consequently, the manager treats the equity market participant and financer's beliefs regarding his earnings management, $\hat{\mathrm{m}}_{\mathrm{e}}$ and $\hat{\mathrm{m}}_{\mathrm{f}}$ respectively, as being unaffected by his actual choice. It follows that, even if the manager's earnings management activities are perfectly anticipated, the manager still engages in earnings management because he would be worse off not managing earnings. ${ }^{2}$

The quadratic nature of the cost function implies that the optimal choice of $\mathrm{m}$ is finite and satisfies the necessary first order condition, which can be expressed as:

$$
\lambda_{\mathrm{e}}-\lambda_{\mathrm{f}}(\mathrm{a}) \mathrm{f}+\lambda_{\mathrm{r}} \mathrm{m}=0
$$

The first term, $\lambda_{\mathrm{e}}$, captures the benefit of a marginal increase in downward earnings management arising from its influence on the beliefs of equity market participants, while the second term, $\lambda_{\mathrm{f}}(\mathrm{a}) \mathrm{f}$, captures the cost of a marginal increase in downward earnings management attributable to its influence on financier beliefs. This second term is critical to our intuition because, assuming external financing is necessary to

\footnotetext{
${ }^{2}$ This reasoning has been used in many analytical models (Narayanan 1985; Stein 1989; and Fischer and Verrecchia 2000) as well as in motivations of empirical work (Erickson and Wang 1999; and Shivakumar 2000).
} 
complete the MBO, it conflicts with the incentive to manage earnings downward to reduce equity price. Finally, the third term captures the change in the expected legal and regulatory costs of decreasing $\mathrm{m}$, which are positive if $m<0$ and negative if $m>0$.

If we impose the standard requirement that the equity and external financing market have rational expectations in equilibrium, we can completely characterize an equilibrium level of earnings management, $\mathrm{m}^{*}$. In a rational expectations equilibrium, $\hat{\mathrm{m}}_{\mathrm{f}}=\hat{\mathrm{m}}_{\mathrm{e}}=\mathrm{m}^{*}$, and $\mathrm{m}^{*}$ is optimal for the manager given that $\hat{\mathrm{m}}_{\mathrm{f}}=\hat{\mathrm{m}}_{\mathrm{e}}=\mathrm{m}^{*}$ (i.e., equation (2) must be satisfied). Hence, it follows that $\mathrm{m}^{*}$ must satisfy equation (2) after substituting in $\mathrm{m}^{*}$ for all $\hat{\mathrm{m}}_{\mathrm{f}}, \hat{\mathrm{m}}_{\mathrm{e}}$ and $\mathrm{m}$. Substituting in $\mathrm{m}^{*}$ into equation (2) and rearranging yields the rational expectations equilibrium $\mathrm{m}^{*}$ :

$$
\mathrm{m}^{*}=\frac{-\lambda_{\mathrm{e}}+\lambda_{\mathrm{f}}(\mathrm{a}) \mathrm{f}}{\lambda_{\mathrm{r}}}
$$

In summary, then, equity market and external financing market participants anticipate that the manager will manage earnings down by $\frac{\lambda_{\mathrm{e}}-\lambda_{\mathrm{f}}(\mathrm{a}) \mathrm{f}}{\lambda_{\mathrm{r}}}$. Hence, in the absence of external financing needs, $\mathrm{f}=0$, downward earnings management equals to $\frac{\lambda_{\mathrm{e}}}{\lambda_{\mathrm{r}}}$, which is consistent with the hypothesis in prior literature.

\subsection{Hypotheses}

A simple comparative static exercise using equation (4) yields our primary hypothesis:

$$
\frac{\mathrm{dm}^{*}}{\mathrm{df}}=\frac{\lambda_{\mathrm{f}}(\mathrm{a})}{\lambda_{\mathrm{r}}}>0
$$

That is, when the MBO buyout group anticipates raising more external funds, managers engage in less downward earnings management, as reflected in a higher $\mathrm{m}$. Hence, we hypothesize:

H1. The level of earnings management in the earnings report issued prior to the MBO offer date is positively associated with the amount of external financing obtained to finance the MBO.

The model yields another testable hypothesis related to external financing concerns. Consider how changes in the amount of fixed assets that can serve as collateral, a, affect the sensitivity of the level 
of downward earnings management to changes in the level of external financing. Differentiating $\frac{\mathrm{dm}^{*}}{\mathrm{df}}$ with respect to the level of fixed assets yields:

$$
\frac{\mathrm{d}^{2} \mathrm{~m}^{*}}{\mathrm{dfda}}=\frac{\lambda_{\mathrm{f}}^{\prime}(\mathrm{a})}{\lambda_{\mathrm{r}}}<0
$$

It follows that, when the firm has more fixed assets to serve as collateral and the MBO group intends to raise more external funds, managers perceive there is less "return" to managing earnings up to appease the external financing market. As a consequence, the sensitivity of earnings management to an increase in external financing is reduced. This finding forms the basis for our second testable hypotheses.

H2. The positive association between the level of earnings management prior to the $M B O$ and the amount of external debt financing is lower when the MBO firm has more physical assets.

We note that both the primary and secondary hypotheses hold even if we assume deviations from perfect rational expectations, such as in Fischer and Verrecchia (2000).

One assumption in the model is that the anticipated level of external financing is fixed and that internal sources of financing vary with differences in the acquisition price induced by differences in the level of earnings management. If the reverse is true so that the level of internal financing is fixed at $\mathrm{f}$ and the level of external financing varies, one might assert that the external financing concerns would magnify the incentives for downward earnings management and eliminate the conflicting reporting incentive. While the first part of the assertion is true, the second part does not follow from the first. Assuming that the level of internal financing is fixed, we can show that (1) the level of earnings management is negatively associated with the level of internal financing, which is intuitively equivalent to $H 1$, and (2) the negative relation between internal financing and level of earnings management is tempered when the MBO firm has more physical assets, which naturally corresponds to $H 2$. Therefore, external financing concerns still provide a conflicting reporting incentive even if the amount of external financing changes dollar for dollar with the equity price. What is required for the tension to exist is that (1) some level of external financing is employed over the range of possible equity prices (P must be weakly greater than $\mathrm{f}$ ) and (2) the incremental cost per unit of external financing must be decreasing in the earnings report. 


\subsection{Validity of critical assumptions}

While the illustrative model generates testable hypotheses, we have not offered much a priori evidence about the validity of the critical underlying assumptions. Below, we discuss more thoroughly the three critical assumptions in the illustrative model: 1) the manager believes that neither equity market participants nor external financing market participants observe whether accruals arise from natural business activities or earnings management activities, 2) accruals that can be managed affect the earnings measure employed by participants in both markets, and 3) external financiers are less responsive to reported performance when more assets are available to secure debt.

In the context of MBOs, the extent to which the first assumption is satisfied for prospective external financiers depends on whether these financiers are privy to a firm's accruals decisions. One might argue that managers will simply manage earnings down to affect the equity market and then privately inform prospective external financiers about that earnings management. Prospective financiers, however, would likely view such disclosures as uninformative cheap talk and, more importantly, such disclosures would magnify shareholder litigation risks. In addition to the a priori reasoning just provided, some anecdotal evidence suggests that external financiers are not always privy to earnings management decisions and, as a consequence, have provided debt financing just prior to failures. ${ }^{3}$ For example, Crazy Eddie Inc. and Crime Control Inc. were found to have manipulated their financial statements prior to raising significant amounts of private debt just before their collapses.

With respect to the second assumption, there exists some evidence suggesting that MBO debt financiers are likely to rely on statistics affected by accruals to predict future cash flows and make credit

\footnotetext{
${ }^{3}$ Admittedly, these anecdotes violate our simple illustrative model because, even if the earnings management is not observable, the assumption in our model is that the external financing market perfectly anticipates it. This violation, however, is entirely attributable to the additional assumption in the model that the external financing market knows the manager's reporting objective function. If this assumption is dropped, as it is in Fischer and Verrecchia (2000), then the external financing market will anticipate earnings management only on average.
} 
decisions. First, financial statement analysis texts identify statistics utilized in credit analysis that are a function of accruals (e.g., earnings, working capital, total assets) (see, e.g., Palepu, Healy, and Bernard 2000 or White, Sondhi, and Fried 1999). Second, practitioner oriented literature provides numerous examples of creditors employing statistics that are a function of accrual decisions. For example, Tran (2000) asserts: “banks often won't lend beyond a conservative multiple of earnings" (emphasis added) (see also Osborn 1984; Kosman 1998). In addition, Eastman (1997) states that earnings before interest, taxes, depreciation, and amortization (EBITDA) is "the most popular measure of cash flow among commercial lenders and credit analysts." ${ }^{, 4}$ Although EBITDA is immune to earnings management through interest, amortization, and tax accruals, it is still subject to earnings management through sales, cost of sales, and other income and expense related accruals. Third, in the academic literature, Dichev and Skinner (2002) document that the three most common ratios used in debt covenants are debt to cash flow, earnings to interest coverage, and earnings to fixed charge coverage. They note that cash flow is often defined in the covenants as either earnings before interest, and taxes (EBIT) or EBITDA, which implies that these ratios are all influenced by some accrual decisions. Because these ratios are used extensively in the debt contracts themselves, one might expect that lenders also use them in their loan authorization and pricing decisions. Finally, a reading of the MBOs' proxy statements reveals that the ratio of debt to EBITDA also determines the rate that lenders charge on the loans and that some lenders require a certain amount of cash, account receivables, and inventory as a condition to finance a transaction. ${ }^{5}$ In sum, the evidence garnered from multiple sources suggests that it is plausible that the second condition is satisfied and that accruals can be used to influence the decisions of external financiers.

The third assumption that external financiers lending decisions are influenced less by measures of financial performance when the MBO firm has a greater established physical asset base also finds some

\footnotetext{
${ }^{4}$ See also Sutherland (1988), Barker (1992), Prager and Block (1992), Hempstead (1999), Ramani (2001), or Sorkin (2007) for discussions of examples where EITDA is employed in the context of MBO financing and valuation.

${ }^{5}$ See, e.g., the proxy statements for the MBOs of Atrix International, Spring Industries, and Westerbeke.
} 
support in the literature. Manove, Padilla, and Pagano (2001) suggest that collateral and screening are substitutes so that a firm with more collateral is likely to incur less intensive screening before credit is granted. Furthermore, Inderst and Müller (2006) suggest that collateral improves a bank's payoffs from financing a project, thus raising the likelihood that credit will be granted at favorable terms. Accordingly, prior empirical studies suggest that credit availability increases in the value of a firm's assets (Fazzari, Hubbard, and Petersen 1988; Kashyap, Lamont, and Stein 1994).

\subsection{Suggestive evidence}

The mixed results reported in extant studies on earnings management prior to MBOs leave open the possibility that external financing concerns may be important determinants of earnings management decisions. More specifically, DeAngelo (1986) finds no evidence of earnings management prior to MBOs while Perry and Williams (1994) find evidence consistent with downward earnings management using a different sample and methodology. Perry and Williams (1994), however, do not find evidence of earnings management for firms in the DeAngelo's sample. As Perry and Williams (1994) argue, the divergence between their results and DeAngelo's results appears to be attributable to the use of different sets of firms as opposed to different methodologies. One dimension along which the two sets of firms differ may be the extent of financing related incentives, in addition to other changes in the economic environment.

In addition to the direct tests of earnings management by DeAngelo (1986) and Perry and Williams (1994), empirical evidence in Kaplan (1989) is consistent with managers' reports being influenced by external financing concerns. Specifically, Kaplan (1989) finds that firms' profitability following buyouts is 6 percent lower than management's forecast at the time of the buyout. This result suggests that, on average, some managers portray over-optimistic prospects for their firms prior to MBOs.

\section{Estimated abnormal current accruals as a proxy for earnings management}

Following the earnings management literature, we proxy for earnings management by measuring a firm's abnormal accruals. We conduct the analysis on the basis of abnormal current accruals because of 
the observation that EBITDA is commonly employed in credit decisions. ${ }^{6}$ In addition, as Healy (1985) argues, long-term accruals, like depreciation, account for little variation in total accruals.

Using all firms that have the necessary data on Compustat, for each two-digit SIC code industry, we estimate the following model for each year:

$$
C A_{i}=\alpha_{0}+\alpha_{1} \Delta S A L E S_{i}+\alpha_{2} L C A_{i}+\varepsilon_{i t}
$$

where $C A$ is current accrual of firm $i ; \triangle S A L E S$ is change in sales; $L C A$ is the lag of $C A$; and $\varepsilon$ is the regression residual. Current accrual is defined as change in non-cash current assets (Compustat data item 4 minus Compustat data item 1) minus change in current liabilities (Compustat data item 5) plus change in the current portion of long-term debt (Compustat data item 44). Missing values for the current portion of long-term debt are set to zero. Both sides of the regression, including the intercept, are scaled by beginning total assets. Each year, we delete the top and bottom 0.5 percentiles of the deflated current and lagged $C A$, and observations that have beginning total assets less than ten million dollars. The model (6) is an extension of the abnormal current accrual models used by Louis (2004), which are modifications of the Jones (1991) model. Following prior studies, we extend the extant abnormal current accrual model by controlling for lagged current accruals. ${ }^{7}$ The model in DeAngelo (1986), where abnormal accruals are the change in accruals from year to year, is the special case of model 1 with $\alpha_{0}=\alpha_{1}=0$ and $\alpha_{2}=1 .^{8}$

${ }^{6}$ We recognize, however, that managers could manipulate EBITDA in manner that affects noncurrent accruals. For example, managers could expense capital expenditures, which would decrease current-period EBITDA, futureperiod depreciation expenses, and potentially current-period depreciation expense.

${ }^{7}$ Prior studies that model current accruals as a function of lagged accruals include Chambers (2001), Dechow, Richardson, and Tuna (2003), Louis and White (2007), and Gong, Louis, and Sun (2008).

${ }^{8}$ The average of the 22 cross-industry average adjusted $R^{2}$ for the fiscal years from 1984 to 2005 is 0.23 . The crossindustry average coefficient on change on sales $(\triangle S A L E S$ ) is positive in 21 (or 95.5\%) of the 22 years. The crossindustry average coefficient on lagged total accruals (LTA) is negative in 21 (or 95.5\%) of the 22 years. The averages of the 22 cross-industry average coefficient estimates are very significant for both variables, with $p$-values 
We adjust our discretionary accrual measure for performance because Dechow, Sloan, Sweeney (1995) and Kothari, Leone, and Wasley (2005) find that estimated discretionary accruals tend to be positively correlated with operating performance. Consistent with Louis (2004) and Gong, Louis, and Sun (2008), among others, each year and for each industry (two-digit SIC code), we create five portfolios by sorting the data into quintiles of return-on-assets (ROA). Discretionary current accruals are proxied by the abnormal current accruals $(A B C A) . A B C A$ for a given firm is the unexplained current accrual (UECA) (i.e., the residual) for that firm minus the median $U E C A$ of the matched portfolio. In addition to controlling for performance, the portfolio-benchmarking approach controls for random effects arising from other events that may affect accruals or other managerial incentives to manage earnings. As Kothari, Leone, and Wasley (2005) suggest, the benchmarking approach succeeds if the differences between the discretionary accruals of the MBO firms and those of the control portfolios effectively proxy for MBO related earnings management.

\section{Sample selection and descriptive statistics}

\subsection{Sample selection}

The study covers completed MBOs with announcement dates between 1985 and 2005. ${ }^{9}$ The sample is obtained from the Security Data Company (SDC)'s online database of mergers and acquisitions. A transaction is included in the sample if: a) the target was a public company before the acquisition; b)

of 0.000 . We find similar results across industries. The average of the 64 time-series average adjusted $R^{2}$ is 0.24 . The time-series average coefficient on $\triangle S A L E S$ is positive for 52 (or 81.3\%) of the 64 two-digit SIC code industries. The time-series average coefficient on $L T A$ is negative for 57 (or 89.1\%) of the 64 industries. The averages of the 64 time-series average coefficient estimates are significant for all three variables, with $p$-values of 0.000 . We require at least eight observations for each estimation.

${ }^{9}$ The sample includes one MBO (9278 Communications) that SDC mistakenly codes as pending. The bid was actually completed; we therefore reclassify it as such. The reclassification does not qualitatively change the results. 
the acquirer is a private company; c) SDC indicates target's management involvement in the acquisition; d) the share of the target that the bidder acquires or attempts to acquire in the transaction is reported by SDC (not including pre-buyout ownership); e) the acquiring firm owns (or attempts to own) 100 percent of the target after the transaction; f) the MBO firm has necessary Compustat data; and g) the amount of funds raised from external sources can be determined from SEC filings, description provided by SDC, and/or news reports on Factiva. There are 200 transactions that satisfy criteria a to f. Of these transactions, 62 do not have enough available information to determine the amount of funds that were raised from external sources. The sample selection process then yields 138 transactions.

Information on the sources of funding for the MBOs comes primarily from proxy statements filed with the SEC. MBO firms file Schedule 14A with the SEC, where they report the amount and sources of funding for the transactions. This information is available through the historical Electronic Data Gathering, Analysis, and Retrieval (EDGAR) archives on the SEC website starting in 1994. In general, a Schedule 14A includes specific information on the total amount needed to purchase the outstanding shares, repay existing debt, pay the MBO fees and expenses, and provide working capital. The filing also provides the amounts of financing from various sources: contribution from management and/or the MBO group, cash balance, and debt financing (secured, subordinated, senior, and junior). External financing is typically the sum of the various forms of debt financing. We set external financing to zero when the filing states that the transaction is not subject to a financing contingency because the firm and/or the acquiring group have sufficient cash on hand. Some cases are relatively more complex, requiring some judgment. For example, Allied Capital uses an existing unsecured credit facility to finance the acquisition of SunSource. In this instance, the credit facility pre-dates the MBO and is granted based on the credit capacity of Allied Capital instead of the credit capacity of SunSource. Therefore, although the transaction is financed with debt, SunSources' pre-MBO financial reporting has no bearing on the lender's financing decision. In such a case, we set external financing to zero. For transactions that do not have information in the historical EDGAR archives (mainly prior to 1994), we rely on information provided by SDC and news reports through Factiva to determine the amount of external funding. A comparison between the 
information on EDGAR and the information provided by SDC for those transactions that took place after 1993 shows that, in general, the information on SDC is reliable, though sometimes incomplete. If the information on SDC is not sufficient to determine the amount of external financing, we complete it with information provided in news reports that we obtain through Factiva. ${ }^{10}$ If we still cannot determine the amount of external financing for a transaction, we remove the observation from the sample.

\subsection{Descriptive statistics}

The characteristics of the sample firms are presented in Table 1. Except for the external financing measures and the share of the company acquired in the MBO, we winsorize the top and bottom onepercentiles (the top and bottom one or two observations) of all the variables. ${ }^{11}$ The mean (median) total financing from external sources is about 64.2 (63.4) percent of total firm value (market value of common equity plus the value of preferred stock (Compustat data item 130) plus total liabilities). The external financing is high relative to total firm value because MBO firms generally need funds to purchase the outstanding shares (usually with a substantial premium -- the average premium is $46.59 \%$ ), pay off existing debt, pay the MBO fees and expenses, and have sufficient working capital for operations. The MBO firms also have large positive book-to-market ratios, ROA, (scaled) EBITDA, and (scaled) cash

\footnotetext{
${ }^{10}$ Because the SEC filings generally provide more information about the source of financing than SDC and press releases, the financing data that we collect from the filings might be more reliable than the data we obtain from SDC and/or in press releases. To assess the potential effects of using financing data from various sources, we conduct separate analyses for the period before and the period after 1994 (the first year when the proxy data are available in the historical EDGAR archives). The results are consistent across the two sub-periods.

${ }^{11} \mathrm{We}$ do not winsorize the external financing variables and the percentage of the shares outstanding acquired in the MBO because external financing is zero for many observations and the percentage of the shares outstanding acquired is 100 for many observations. For these variables, winsorization would affect only one tail of the distribution. Also, because the percentage acquired is limited at 100 , this variable is unlikely to be affected by outliers or very large data errors.
} 
flow from operations: with means (medians) of 0.877 (0.754), $0.144(0.156)$, and 0.097 (0.100), respectively. Consistent with the conjecture that managers deflate accruals prior to MBOs, (scaled) current accruals are negative with a mean (median) of $-0.010(-0.007)$. The (scaled) change in capital expenditures is also negative with a mean (median) of -0.008 (-0.002). The reduction in capital expenditures is also consistent with the notion that managers have incentives to deflate reported earnings prior to MBOs. They can recognize some capital expenditures as expenses, which would reduce both capital expenditures and earnings. We recognize, however, that capital expenditures can also be lower if managers delay making investments to conserve cash to finance the MBOs.

Table 1 also compares the characteristics of firms with the lowest levels of external financing to those of firms with the highest levels of external financing. External financing is deemed low (high) if total external financing is the bottom (top) quartile of the external financing distribution within our sample firms. Comparing the bottom and top quartiles is likely to mitigate potential noise that might be associated with measurement errors in computing total external financing. External financing is deflated by total firm value. ${ }^{12}$ Because the $\mathrm{MBO}$ group generally has to both purchase the outstanding shares and pay off the existing debts, we want the deflator to reflect both the MBO firm's equity and debt.

The proportion of the company acquired in the MBO transaction is significantly lower for the low external financing firms. The low external financing firms have significantly lower ROA, EBITDA, and current accruals. They also have significantly more negative changes in capital expenditures, which is consistent with the conjecture that the low external financing firms have stronger incentives to expense capital expenditures. Actually, both current accruals and change in capital expenditure are negative for the low external financing firms and positive for the high external financing firms. There is no evidence that depreciation expenses, special items, cash flow from operations, the market reaction to the MBO announcement, or the MBO premium are different across the two groups of firms.

\footnotetext{
${ }^{12}$ We cannot deflate by total financing because, in general, total financing is not available prior to 1994.
} 


\section{Earnings management prior to MBOs}

Perry and Williams (1994) document that abnormal accruals are, on average, negative in the year prior to MBOs for a sample of transactions that took place in the 1970s and 1980s. Since the 1980's, however, pre-MBO financial reporting incentives may have changed in a significant manner. For example, Congress passed the Private Securities Litigation Reform Act in 1995 and the Securities Litigation Uniform Standards Act in 1998, which might have mitigated managers' concerns about litigation associated with the pre-MBO financial reporting. Because our sample comprises a more recent period in which reporting incentives may have differed, we first assess whether the pattern of abnormal accruals established for the earlier sample period persists in our sample period.

The results are reported in Panel A of Table 2. Consistent with Perry and Williams (1994), we find significantly negative abnormal current accruals in the fiscal year ending immediately prior to the MBO announcements (Year 0). To ensure that our results capture the effects of the MBOs, we compare the abnormal current accruals for Year 0 with the abnormal current accruals for Year-2 (the fiscal year ending within 25 to 36 months prior to the MBO announcement). Consistent with the conjecture that the income-decreasing abnormal current accruals are related to the MBOs, we find no evidence of incomedecreasing abnormal current accruals in Year-2. ${ }^{13}$ To assess whether the results are sensitive to the potential effects of changes in the structure of MBO financing, we divide the sample period into two subperiods of 10 years each: 1985-1994 and 1996-2005. We do not have any sample observation in 1995.

\footnotetext{
${ }^{13}$ We use Year-2 instead Year-1 because some managers could start planning an MBO more than a year in advance; therefore, the observations for Year-1 could be contaminated. However, we obtain qualitatively similar results if we use Year-1 instead of Year-2. There are 126 sample firms that have necessary data in both Year 0 and Year-1. For these firms, the mean (median) unexpected current accruals in Year 0 are $-0.024(-0.009)$ and the mean (median) abnormal current accruals are $-0.026(-0.010)$, with $p$-values below $1 \%$. In contrast, the mean (median) unexpected current accruals in Year-1 are -0.004 (0.007) and the mean (median) abnormal current accruals are $-0.009(0.000)$. They are all statistically insignificant.
} 
The results for the subperiods are reported in Panel B of Table 2. We find evidence of accrual management for both sub-periods. Although there seems to be more downward earnings management in the later period, the difference is not statistically significant.

Table 3 provides some univariate analysis pertaining to our primary hypothesis that, on average, firms that rely more on debt financing deflate earnings less. In Panel A, we compare the abnormal current accruals of firms that rely the most on financing from external sources (top quartile of scaled external financing) with abnormal current accruals of firms that rely the least on financing from external sources (bottom quartile of scaled external financing). Consistent with $H 1$, we find that firms that rely the most on financing from external sources report significantly less downward abnormal current accruals than firms that rely the least on financing from external sources. ${ }^{14}$ In Panel B, we compare the sample firms with the Compustat population. We make the comparison across firms with no debt issuance and those in the top decile of the distribution of debt issuance (scaled by total firm value at the beginning of the fiscal year) using all firms on Compustat that have necessary observations. ${ }^{15}$ For the MBO firms, we use the amount raised from external sources to finance the MBO (scaled by total firm value). Consistent with our expectations, we find that (1) firms in the top decile of external financing report higher abnormal current accruals across both the MBO firms and the Compustat population and (2) the MBO firms report more negative abnormal current accruals than the population across both external financing groups.

Table 4 reports the industry distribution of the abnormal accruals by the level of external financing. The MBOs are most concentrated in the manufacturing sector (59 out of 138 or 42.45 percent).

\footnotetext{
${ }^{14} \mathrm{We}$ obtain qualitatively similar results if we use the median. The one-tail $p$-value for the difference in the median abnormal current accruals (unexplained current accruals) between firms that rely the most on financing from external sources and those that rely the least on financing from external sources is $0.004(0.005)$.

${ }^{15}$ Note that the decile ranking is based on the entire Compustat population. The finer ranking (decile instead of quartile) is necessary to ensure that the control firms have the same level of debt as the sample firms. Most of our sample firms (101 of 138) are in the top decile of debt financing.
} 
Abnormal current accruals are negative in all three major industrial sectors: manufacturing, merchandising, and services. ${ }^{16}$ Firms that rely the most on financing from external sources tend to report less downward abnormal accruals than firms that rely the least on financing from external sources across all the industrial groups.

\section{Regression analysis}

\subsection{Conditional association between earnings management and external financing}

We estimate the conditional association between abnormal current accruals prior to MBO announcements and external financing using the following regression model:

$$
A B C A_{i}=\alpha_{1} S E F_{i}+\alpha_{2} S P P E_{i}+\alpha_{3} S E F_{i} * S P P E_{i}+\alpha_{4} C N T R_{i}+\alpha_{5} B M_{i}+\text { Year Fixed Effect }+\varepsilon_{i .}
$$

where $A B C A$ is the abnormal current accrual for the fiscal year that immediately precedes the $\mathrm{MBO}$ announcement; $S E F$ is total financing from external sources scaled by total firm value; SPPE is beginning net property, plant, and equipment (PP\&E) scaled by total firm value; CNTR is the proportion of the company controlled by the $\mathrm{MBO}$ group prior to the $\mathrm{MBO}$, defined as $1-A C Q$, where $A C Q$ is the proportion of the company acquired in the MBO transaction; and $B M$ is book value of equity divided by market value of equity at the beginning of the fiscal year.

We expect a positive coefficient on $S E F$ and a negative coefficient on the interaction between $S E F$ and SPPE. We control for CNTR because managers' incentives to deflate earnings prior to an MBO is likely to decrease as the share of the company they already control increases. Gong, Louis, and Sun (2008), for instance, find that managers' incentives to deflate earnings prior to share repurchases increase with the share of the company that they actually repurchase. We control for $B M$ because the stock prices of growth and value firms have different sensitivities to earnings and, therefore, managers of such firms

\footnotetext{
${ }^{16}$ The sample does not include any bank because current assets and current liabilities - the two main variables used to compute current accruals -- are not available on Compustat for banks. The sample includes five other financial service firms; we group them into "services".
} 
could have different incentives to manage earnings. We include year fixed effects to control for the potential effects of changes in the structure of MBO financing over the years. ${ }^{17}$

The results of the regression analysis are reported in Panel A of Table 5. Consistent with the results from the univariate analysis, we find a significantly positive association between external financing and pre-MBO abnormal current accruals. The coefficient on the interaction between external financing and PP\&E is significantly negative, which is consistent with the conjecture that the effect of external financing on the marginal cost of managing earnings down prior to MBOs increases when a firm has few physical assets that it can use as collateral.

The scaled external financing measure is arguably more appropriate than the un-scaled measure to proxy for external financing because, everything else equal, a firm that has, for instance, a value of \$20 million and external financing of $\$ 18$ million is more reliant on external financing than a firm that has a value of, say, $\$ 100$ million and external financing of $\$ 30$ million. Therefore, external financing should be scaled to account for the size of the firm.

On the other hand, as the total amount of external funds needed to finance the transaction increases, so does the difficulty to secure the financing, even after considering the firm value. As Kosman (1998) observes, there are specific difficulties associated with financing large buyouts, suggesting that unscaled external financing can be more relevant than the scaled measure in capturing the difficulty of obtaining financing. Therefore, we also express external financing $(E F)$ and $P P E$ in levels. More specifically, we use the following regression model:

\footnotetext{
${ }^{17}$ Prior studies suggest that political costs and leverage are related to managers' incentives to manage earnings. Controlling for size (as a proxy for political costs) and leverage do alter our inferences. However, we do not include these variables in our model because they are not relevant in our setting. MBO firms are relatively small and are concerned mainly about their ability of raising the funds to finance the transaction. The effect of the financing concern is captured by $E F$ in our model.
} 


$$
\begin{aligned}
A B C A_{i}= & \alpha_{1} L O G E F_{i}+\alpha_{2} L O G P P E_{i}+\alpha_{3} L O G E F_{i} * L O G P P E_{i}+\alpha_{4} C N T R_{i}+\alpha_{5} B M_{i} \\
& + \text { Year Fixed Effect }+\varepsilon_{i},
\end{aligned}
$$

where $L O G E F$ is the logarithm of $E F$, $[\log (1+E F)]$ and LOGPPE is the logarithm of PPE. We use the $\log$ transformation of these variables because their distributions are skewed. The log transformation is also likely to mitigate potential nonlinearity and heteroskedasticity problems. ${ }^{18}$ The results, reported in Panel B of Table 5, are consistent with the main results reported in Panel A.

To provide further evidence that the results are driven by the MBO transaction, as opposed to some other generic predictors of accruals, we also estimate the model for the second year prior to the preMBO year. We measure $A B C A$ over the fiscal year ending within 25 to 36 months prior to the MBO announcement (Year-2). We also measure PPE and $B M$ at the beginning of Year-2. The other variables, LOGEF and CNTR are measured as in Model 7A. Because the predictions are conditioned on the occurrence of the buyouts, we expect them to hold for the pre-MBO year (Year 0), but not for Year-2. The results are reported in Table 6 . There are 108 MBOs that have the necessary data in both Year 0 and Year-2. Hence, in Table 6, we report the results for the 108 firms in Year 0, which replicates Table 5, and for those same firms in Year-2. The results are generally consistent with those reported in Table 5 for Year 0 . However, none of the coefficients is significantly different from zero in Year-2, suggesting that the documented effects are attributable to the buyouts.

\subsection{Controlling for the effect of endogeneity}

As was suggested in the discussion of the illustrative model, the level external financing may be endogenous because the amount of external financing could be a function of the pre-MBO earnings

\footnotetext{
${ }^{18}$ To mitigate the potential effects of outliers, we winsorize the top and bottom one-percentiles of $A B C A, L O G P P E$, and PPE/ASSET. Because the sample has only 138 observations, the winsorization affects only a few observations. To further ensure that the results are not driven by a few observations, we use Cook's (1977) $D$ Influence statistics to test for influential observations. None of the $D$ statistics is over one; therefore, there is no evidence that the results are driven by influential observations.
} 
management. ${ }^{19}$ To address the endogeneity problem, we use an instrumental variables approach. In a firststage regression, we model external financing $(S E F)$ as a function of a set of instrumental variables and then, in a second-stage regression, we replace $S E F$ in Model 7A with $P S E F$, the predicted value of $S E F$ from the first-step regression. More specifically, we use the following models:

$$
\begin{aligned}
S E F_{i}= & \alpha_{1} A C Q_{i}+\alpha_{2} S C A S H_{i}+\alpha_{3} C_{A P E X_{i}}+\alpha_{4} L E V E R A G E_{i}+\alpha_{5} L_{A G R O A_{i}+\alpha_{5} L O G V A L U E_{i}} \\
& + \text { Industry Fixed Effect }+ \text { Year Fixed Effect }+\varepsilon_{i} \\
A B C A_{i} & =\alpha_{1} P S E F_{i}+\alpha_{2} S P P E_{i}+\alpha_{3} \text { PSEF }_{i} * S P P E_{i}+\alpha_{4} C N T R_{i}+\alpha_{5} B_{i}+\text { Year Fixed Effect } \\
& +\varepsilon_{i},
\end{aligned}
$$

where $A C Q$ is the proportion of the company acquired in the MBO transaction, $S C A S H$ is cash balance scaled by total firm value at the beginning of the year prior to the MBO announcement, CAPEX is capital expenditures in the year prior to the $\mathrm{MBO}$ announcement scaled by beginning assets, LEVERAGE is total liabilities divided by total assets at the beginning of the year prior to the $\mathrm{MBO}$ announcement, LAGROA is return-on-assets for the year prior to the pre-MBO year, LOGVALUE is the logarithm of firm value, and the industry-fixed effects are indicator variables for manufacturing, merchandising, and service firms, respectively. The other variables are defined as before.

We include $S C A S H$ in the model because the need for external financing is likely to decrease in the amount of cash that the firm already has on hand. We include CAPEX because firms with recent investments in capital expenditures are probably more attractive to lenders, which would enable the firms to raise funds more easily from external sources. We add LEVERAGE and LAGROA because a firm's ability to obtain external financing is likely to decrease in the amount of debt it already has and to increase in its profitability. Finally, we include $L O G V A L U E$ because, all else equal, it is more difficult for a firm to raise external funds to finance a large acquisition.

\footnotetext{
${ }^{19}$ If the rational expectations assumption employed in the model is literally true, which is arguably unlikely, then this particular endogeneity problem does not arise because, in equilibrium, the equity purchase price is independent of the equilibrium level of earnings management.
} 
The results for the first-stage regression are reported in Panel A of Table 7. The model is very powerful with an adjusted $R^{2}$ of 0.855 when the industry dummies and the year-fixed effects are included in the model and 0.443 when they are excluded. The coefficients on ACQ, CAPEX, and LAGROA are significantly positive and the coefficients on SCASH, LEVERAGE, and LOGVALUE are significantly negative. The results for the second-step regression are reported in Panel B of Table 7. They are qualitatively similar to those reported in Table 5. More specifically, the coefficients on the predicted value of external financing $(P S E F)$ is significantly positive, supporting the conjecture that firms that rely more on debt financing report less negative abnormal accruals prior to MBOs. The coefficient on the interaction between external financing and $\mathrm{PP} \& \mathrm{E}$ is also significantly negative, which is consistent the conjecture that the effect of external financing on the marginal cost of managing earnings down prior to MBOs increases when a firm has few physical assets that it can use as collateral.

\section{Summary and conclusion}

When managers issue financial statements, they generally have conflicting reporting incentives because they face different user groups. One case where such a conflicting reporting incentive is likely to arise is when managers anticipate doing an MBO. Prior studies have suggested that managers would like to reduce equity market perceptions of the firm's value in order to reduce the purchase price. The equity market incentive implies that managers would manage earnings downwards in anticipation of an MBO. We suggest that managers would also like to enhance prospective external financiers' perceptions of the firm's value in order to secure financing. The incentive to appeal to financiers suggests that managers would manage earnings upwards in anticipation of an MBO. Thus, managers face a conflicting reporting incentive arising from financing concerns. We also conjecture that the countervailing financing incentive should decrease with total fixed assets.

The results are consistent with the existence of the conflicting reporting incentive arising from external financing concerns. We find that firms that use more external funds to finance their MBO report less negative abnormal accruals. We also find that the positive effect of external financing on earnings management decrease as the amount of fixed assets increases, which is consistent with the conjecture that 
the effect of external financing on the marginal cost of managing earnings down prior to MBOs increases as the firm has fewer physical assets that it can use as collateral.

Our results have relevance to regulators who are concerned with equity investors being subject to earnings management prior to MBOs and, more generally, other significant corporate events. In particular, with respect to MBOs, our results suggest that conflicting reporting incentives mitigate the incentives to manage earnings to take advantage of equity investors. The results also suggest that users of financial statements should carefully assess the magnitudes of conflicting reporting incentives when interpreting financial reports. 


\section{Acknowledgments}

This paper benefits from comments by two anonymous referees, Orie Barron, Anne Beatty, Christine

Cheng, Charles Enis, Steven Huddart, Bin Ke, James McKeown, Sarah Peck, Hal White, and workshop participants at Penn State University and the 2006 American Accounting Association annual conference. 


\section{References}

Barker, R., 1992, What makes a good leveraged buyout?, The Secured Lender 48, 22-24.

Buccino, G., 1989, Crisis management: Are LBOs an emerging problem?, The Secured Lender 45, 26-29.

Buyouts Staff, 2003, Banks finally loosen the purse strings, Buyouts (August 11): 1.

Chambers, D., 2001, Earnings management, income smoothing, and capital market misallocation, Unpublished Working Paper.

Chou, D., M. Gombola, and F. Liu, 2006, Earnings management and stock performance of leverage buyouts, Journal of Financial and Quantitative Analysis 41, 407-438.

Cook, R., 1977, Detection of influential observations in linear regression, Technometrics 19, 15-18.

DeAngelo, L., 1986, Accounting numbers as market valuation substitutes: A study of management buyouts of public stockholders, Accounting Review 61, 400-420.

DeAngelo, H, L. DeAngelo, and E. Rice, 1984, Going private: Minority freezeouts and stockholder wealth, Journal of Law and Economics 27, 367-401.

Dechow, P., S. Richardson, and I. Tuna, 2003, Why are earnings kinky? An examination of the earnings management explanation, Review of Accounting Studies 8, 355-384.

Dechow, P., R. Sloan, A. Sweeney, 1995, Detecting earnings management, Accounting Review 70, 193225.

Dichev, I. and D. Skinner, 2002, Large-sample evidence on the debt covenant hypothesis, Journal of Accounting Research 40, 1091-1123.

Dye, R. and S. Sridhar, 2004, Reliability-relevance trade-offs and the efficiency of aggregation, Journal of Accounting Research 42, 51-88.

Eastman, K., 1997, EBITDA: An overrated tool for cash flow analysis, Commercial Lending Review 12, 64-69.

Engel, E., R. Hayes, and X. Wang, 2007, The Sarbanes-Oxley Act and firms' going-private decisions, Journal of Accounting and Economics 44, 116-145. 
Erickson, M., and S. Wang, 1999, Earnings management by acquiring firms in stock for stock mergers, Journal of Accounting and Economics 27, 149-176.

Fischer, P. and R. Verrecchia, 2000, Reporting bias, The Accounting Review 75, 229-245.

Fazzari, S., R. Hubbard, and B. Petersen, 1988, Financing constraints and corporate investment, Brookings Papers on Economic Activity 88, 141-195.

Gong, G., H. Louis, and A. Sun, 2008. Earnings management and firm performance following openmarket repurchases, Journal of Finance (forthcoming).

Healy, P., 1985, The effect of bonus schemes on accounting decisions, Journal of Accounting and Economics 7, 85-107.

Hempstead, J., 1999, How to get the loan you need, Folio: The Magazine for Magazine Management 27, 192-193.

Inderst, R. and H. Müller, forthcoming, A lender-based theory of collateral, Journal of Financial Economics.

Jensen, M., 1986, Agency costs of free cash flow, corporate finance, and takeovers, American Economic Review 76, 323-329.

Jones, J., 1991, Earnings management during import relief investigations, Journal of Accounting Research 29, 193-228.

Kaplan, S., 1989, Management buyouts: Evidence on taxes as a source of value, The Journal of Finance $44,611-632$.

Kashyap, A., O. Lamont, and J. Stein, 1994, Credit conditions and the cyclical behavior of inventories, Quarterly Journal of Economics 109, 565-592.

Kosman, J., 1998, Do lenders' woes bring a silver lining, Buyouts (October 26): 1.

Kothari, S., A. Leone, and C. Wasley, 2005, Performance matched discretionary accrual measures, Journal of Accounting and Economics 39, 163-197.

Louis, H., 2004, Earnings management and the market performance of acquiring firms, Journal of Financial Economics 74, 121-148. 
Louis, H., and H. White, 2007, Do managers intentionally use repurchase tender offers to signal private information? Evidence from firm financial reporting behavior, Journal of Financial Economics 85, 205-233.

Manove, M., A. Padilla, and M. Pagano, 2001, Collateral versus project screening: A model of lazy banks, Rand Journal of Economics 32, 726-744.

Masulis, R., 1980, The effects of capital structure change on security prices: A study of exchange offers, Journal of Financial Economics 8, 139-178.

Narayanan, M., 1985, Managerial incentives for short-term results, Journal of Finance 40, 1469-1484.

Nelson, J., 1985, Gathering grief with the gold?, United States Banker 96, 18-21.

Osborn, N., 1984, Leveraged buyouts: Too good to be true?, Euromoney (April), 20-22.

Palepu, K., P. Healy, and V. Bernard, 2000. Business Analysis and Valuation: Using Financial Statements, $2^{\text {nd }}$ Edition. Cincinnati: Southwestern Publishing.

Perry, S. and T. Williams, 1994, Earnings management preceding management buyout offers, Journal of Accounting and Economics 18, 157-179.

Prager, M., and B. Block, 1992, Protecting secured lenders in the structuring and workout of LBO-related financing, Commercial Lending Review 7, 11-20.

Ramani, V., 2001, The SFD/EBITDA ratio and the asset-based lender, The Secured Lender 57, 86 - 87.

Shivakumar, L., 2000, Do firms mislead investors by overstating earnings before seasoned equity offerings? Journal of Accounting and Economics 29, 339-371.

Sorkin, A., 2007, Will the Bancrofts sell Dow Jones? DealBook (May 2) http://dealbook.blogs. nytimes.com/2007/05/02/will-the-bancrofts-sell-dow-jones/\#more-13929.

Stein, J., 1989, Efficient capital markets, inefficient firms: A model of myopic corporate behavior, Quarterly Journal of Economics 104: 655-670.

Sutherland, F., 1988, Squeezing cash: How to make an LBO work, Corporate Cashflow 9, 47-49.

Teoh, S., I. Welch, and T. Wong, 1998, Earnings management and the underperformance of seasoned equity offerings, Journal of Financial Economics 50, 63-99. 
Tran, H., 2000, Lenders shun risk, alter buyout industry, Buyouts (March 20): 1.

Weston, J., K. Chung, and J. Siu, 1997, Takeovers, Restructuring, and Corporate Governance, Prentice Hall, $2^{\text {nd }}$ ed., 316-343.

White, G., A. Sondhi, and D. Fried, 1999, The analysis and use of financial statements, John Wiley \& Sons, Inc., $2^{\text {nd }}$ ed.. 
Table 1

Descriptive statistics

ASSET is beginning total assets (in millions of dollars); $B M$ is book value of equity divided by market value of equity at the beginning of the fiscal year; $E F$, external financing, is the total amount of financing (in millions of dollars) raised from entities that are not associated with management or the MBO group; FIRM_VALUE is market value of common equity plus the value of preferred stock (Compustat data item 130) plus total liabilities (in millions of dollars); $S E F$ is EF scaled by FIRM_VALUE; ACQ is the proportion of the company acquired in the MBO transaction; $S C A S H$ is cash balance scaled by FIRM_VALUE; ACQ is the proportion of the company acquired in the MBO transaction; SPPE is net beginning property plant and equipment scaled by FIRM_VALUE; DEBT is total beginning long-term debt; DEBT-TO-ASSET is the ratio of beginning long-term debt to ASSET; ROA is net income before extraordinary items and discontinued operations scaled by ASSET; EBITDA is earnings before interest, taxes, depreciation, and amortization (Compustat data item 13) scaled by ASSET; CFO is cash flow from operations scaled by ASSET; $C A$ is current accruals scaled by ASSET; DEP is depreciation and amortization scaled by ASSET; SI is special items scaled by ASSET; CHCAPEX is change in capital expenditures (Compustat data item 128) scaled by ASSET; CAR is the market adjusted return over the week centered on the MBO announcement; and PREMIUM is the offer price premium over the stock price four weeks prior to the MBO announcement. All the variables are defined in the fiscal year prior to the MBO announcement. External financing is deemed low (high) if total external financing (scaled by firm value) is the bottom (top) quartile of the external financing distribution within our sample firms. ${ }^{+++} I^{++} I^{+}$indicates that the difference between "high" and "low" external financing firms is significant at the $1 \% / 5 \% / 10 \%$ level in a one-tail test. The tests of mean differences are based on the $t$-statistic, assuming unequal variances, and the tests for median differences are based on the Wilcoxon two-sample statistic.

\begin{tabular}{|c|c|c|c|c|c|c|c|c|c|}
\hline \multirow[t]{2}{*}{ Variables } & \multicolumn{3}{|c|}{ Full sample } & \multicolumn{3}{|c|}{ Low external financing } & \multicolumn{3}{|c|}{ High external financing } \\
\hline & $\mathrm{N}$ & Mean & Median & $\mathrm{N}$ & Mean & Median & $\mathrm{N}$ & Mean & Median \\
\hline$\overline{A S S E T}$ & 138 & 235.334 & 93.114 & 34 & 174.659 & 67.541 & 34 & 150.835 & 67.854 \\
\hline$B M$ & 138 & 0.877 & 0.754 & 34 & 0.788 & 0.806 & 34 & 0.756 & 0.578 \\
\hline$E F$ & 138 & 196.696 & 63.150 & 34 & 30.947 & 0.000 & 34 & $224.854^{+++}$ & $139.000^{+++}$ \\
\hline FIRM_VALUE & 138 & 302.211 & 118.947 & 34 & 208.581 & 66.359 & 34 & 218.481 & 113.107 \\
\hline$S E F$ & 138 & 0.642 & 0.634 & 34 & 0.084 & 0.000 & 34 & $1.204^{+++}$ & $1.218^{+++}$ \\
\hline SCASH & 138 & 0.135 & 0.044 & 34 & 0.254 & 0.110 & 34 & $0.073^{+++}$ & $0.042^{+++}$ \\
\hline$A C Q$ & 138 & 82.738 & 100.000 & 34 & 68.246 & 63.455 & 34 & $98.650^{+++}$ & $100.000^{+++}$ \\
\hline$S P P E$ & 138 & 0.310 & 0.258 & 34 & 0.254 & 0.180 & 34 & 0.315 & 0.276 \\
\hline DEBT-TO-ASSET & 138 & 0.237 & 0.212 & 34 & 0.281 & 0.139 & 34 & 0.216 & 0.188 \\
\hline$R O A$ & 138 & 0.030 & 0.047 & 34 & -0.058 & 0.008 & 34 & $0.068^{+++}$ & $0.063^{+++}$ \\
\hline EBITDA & 137 & 0.144 & 0.156 & 33 & 0.064 & 0.079 & 34 & $0.201^{+++}$ & $0.191^{+++}$ \\
\hline $\mathrm{CFO}$ & 137 & 0.097 & 0.100 & 33 & 0.074 & 0.076 & 34 & 0.087 & 0.097 \\
\hline$C A$ & 138 & -0.010 & -0.007 & 34 & -0.068 & -0.044 & 34 & $0.038^{+++}$ & $0.011^{+++}$ \\
\hline$D E P$ & 137 & 0.054 & 0.046 & 33 & 0.057 & 0.042 & 34 & 0.058 & 0.053 \\
\hline$S I$ & 134 & -0.004 & 0.000 & 33 & -0.018 & 0.000 & 34 & -0.007 & 0.000 \\
\hline СНCAРEX & 138 & -0.008 & -0.002 & 34 & -0.019 & -0.010 & 34 & $0.006^{++}$ & $0.002^{++}$ \\
\hline$C A R$ & 115 & 24.893 & 22.700 & 27 & 28.945 & 24.510 & 30 & 23.592 & 27.205 \\
\hline PREMIUM & 112 & 46.587 & 44.070 & 28 & 48.506 & 50.300 & 28 & 45.016 & 46.420 \\
\hline
\end{tabular}


Table 2

Abnormal current accruals prior to MBOs

Discretionary current accrual is proxied by the difference between the abnormal current accrual $(A B C A)$ of a firm and the median abnormal current accrual of a portfolio matched on industry and performance. We refer to the difference as the matched $A B C A$. The (unmatched) $A B C A$ is the residual of the following regression: $C A_{i}=\alpha_{0}+\alpha_{1} \triangle S A L E S_{i t}+\alpha_{2} L C A_{i t}+\varepsilon_{i t}$, where $C A$ is current accrual; $\triangle S A L E S$ is change in sales; $L C A$ in the lag of $C A$; and $\varepsilon$ is the regression residual. Both sides of the regression are scaled by beginning total assets. The regression is estimated by year and (two-digit SIC code) industry, using all firm-years that have the necessary observations on Compustat. Year 0 refers to the fiscal year ending within 1 to 12 months prior to the MBO announcement and Year-2 refers to the fiscal year ending within 25 to 36 months prior to the MBO announcement. In Panel A, we use two sets of firms. In the first set, we require that a firm have necessary data in Year 0 only; the number of observations is 138 . In the second set, we require that a firm have necessary data in both Year 0 and Year-2; the number of observations is 108. In Panel B, we report results for the first set only. One-tail $p$-values are presented in brackets and two-tail $p$-values in parentheses. They are based on the $t$-test for the mean and the Wilcoxon signed rank test for the median. We winsorize the top and bottom observations of the discretionary current accrual measures.

Panel A: Abnormal current accruals in Year 0 and Year-2 for the full sample

\begin{tabular}{|c|c|c|c|c|c|c|}
\hline & \multicolumn{2}{|c|}{$\begin{array}{l}\text { Year } 0 \text { (Full sample) } \\
\qquad(N=138)\end{array}$} & \multicolumn{2}{|c|}{$\begin{array}{l}\text { Year } 0 \text { (Restricted } \\
\text { sample) }\end{array}$} & \multicolumn{2}{|c|}{$\begin{array}{c}\text { Year-2 (Restricted sample) } \\
\qquad(N=108)\end{array}$} \\
\hline & $\begin{array}{l}\text { Unmatched } \\
A B C A\end{array}$ & $\begin{array}{c}\text { Matched } \\
A B C A\end{array}$ & $\begin{array}{l}\text { Unmatched } \\
A B C A\end{array}$ & $\begin{array}{l}\text { Matched } \\
A B C A\end{array}$ & $\begin{array}{l}\text { Unmatched } \\
\qquad A B C A\end{array}$ & $\begin{array}{l}\text { Matched } \\
A B C A\end{array}$ \\
\hline Mean & $\begin{array}{c}-0.021 \\
{[0.001]}\end{array}$ & $\begin{array}{c}-0.023 \\
{[0.001]}\end{array}$ & $\begin{array}{l}-0.019 \\
{[0.007]}\end{array}$ & $\begin{array}{c}-0.021 \\
{[0.003]}\end{array}$ & $\begin{array}{l}-0.002 \\
(0.756)\end{array}$ & $\begin{array}{l}-0.003 \\
(0.655)\end{array}$ \\
\hline Median & $\begin{array}{c}-0.009 \\
{[0.001]}\end{array}$ & $\begin{array}{c}-0.010 \\
{[0.001]}\end{array}$ & $\begin{array}{c}-0.009 \\
{[0.007]}\end{array}$ & $\begin{array}{c}-0.007 \\
{[0.004]}\end{array}$ & $\begin{array}{c}0.004 \\
(0.681)\end{array}$ & $\begin{array}{c}0.008 \\
(0.652)\end{array}$ \\
\hline
\end{tabular}

Panel B: Abnormal current accruals in Year 0: Earlier versus later years

\begin{tabular}{cccccc}
\hline & \multicolumn{2}{c}{$\begin{array}{c}1985-1994 \\
\end{array}$} & & & \multicolumn{2}{c}{$\begin{array}{c}1996-2005 \\
(N=75)\end{array}$} \\
\cline { 2 - 3 } \cline { 5 - 6 } & Unmatched $A B C A$ & Matched $A B C A$ & & Unmatched $A B C A$ & Matched $A B C A$ \\
\hline \multirow{3}{*}{ Mean } & -0.013 & -0.013 & & -0.028 & -0.030 \\
& {$[0.060]$} & {$[0.053]$} & & {$[0.005]$} & {$[0.002]$} \\
& -0.009 & -0.007 & & -0.008 & -0.014 \\
& {$[0.017]$} & {$[0.012]$} & & {$[0.020]$} & {$[0.007]$} \\
\hline
\end{tabular}


Table 3

Average abnormal current accruals in the year immediately prior to the MBO announcement by the level of external financing

In Panel A, external financing is deemed low (high) if total external financing (scaled by total firm value at the beginning of the fiscal period) is the bottom (top) quartile of the external financing distribution within the sample firms. The two sub-periods are: 1985-1994 and 1996 - 2005. The sample has no observation in 1995. In Panel B, the top decile of external financing is based on the distribution of debt issuance (scaled by total value of the firm at the beginning of the fiscal period) for all the firms on Compustat that have necessary observations. For the MBO firms, external financing $(S E F)$ is the amount raised from external sources to finance the MBO (scaled by total firm value at the beginning of the fiscal period). Discretionary accrual is as defined in Table 2. It is measured in the year prior to the debt issuance. One-tail $p$-values are presented in brackets and two-tail $p$-values in parentheses.

Panel A: Full sample and cross-period comparison

\begin{tabular}{lcccc}
\hline & \multicolumn{3}{c}{ Level of external financing } & Difference \\
\cline { 2 - 4 } Full sample & Low & Medium & High & High - Low \\
& $(N=34)$ & $(N=70)$ & $(N=34)$ & \\
\hline Unmatched ABCA & -0.051 & -0.023 & 0.013 & 0.064 \\
Matched $A B C A$ & {$[0.000]$} & {$[0.011]$} & $(0.317)$ & {$[0.000]$} \\
Earlier years: $1985-1994$ & -0.049 & -0.025 & 0.009 & 0.058 \\
& {$[0.001]$} & {$[0.005]$} & $(0.456)$ & {$[0.001]$} \\
Unmatched ABCA & Low & Medium & High & High - Low \\
Matched $A B C A$ & $(N=15)$ & $(N=32)$ & $(N=16)$ & \\
Later years: $1996-2005$ & -0.029 & -0.023 & 0.023 & 0.052 \\
& {$[0.038]$} & {$[0.026]$} & $(0.175)$ & {$[0.008]$} \\
Unmatched $A B C A$ & -0.033 & -0.022 & 0.023 & 0.056 \\
& {$[0.032]$} & {$[0.028]$} & $(0.135)$ & {$[0.013]$} \\
Matched $A B C A$ & Low & Medium & High & High - Low \\
& $(N=18)$ & $(N=38)$ & $(N=19)$ & \\
& -0.070 & -0.022 & 0.000 & 0.071 \\
& {$[0.002]$} & {$[0.008]$} & $(0.985)$ & {$[0.010]$} \\
& -0.063 & -0.027 & -0.005 & 0.058 \\
& {$[0.006]$} & {$[0.031]$} & $(0.800)$ & {$[0.027]$} \\
\hline
\end{tabular}

Panel B: MBO firms versus Compustat population

\begin{tabular}{|c|c|c|c|c|c|c|c|c|c|}
\hline & \multicolumn{3}{|c|}{ No external financing } & \multicolumn{4}{|c|}{ Top decile of external financing } & \multicolumn{2}{|c|}{ Difference } \\
\hline & $N$ & Unmatcher & Matched & $N$ & SEF & Unmatche & Matched & Unmatchec & Matched \\
\hline & & $A B C A$ & $A B C A$ & & & $\triangle B C A$ & $A B C A$ & $A B C A$ & $A B C A$ \\
\hline MBO firms & 19 & $\begin{array}{c}-0.080 \\
{[0.009]}\end{array}$ & $\begin{array}{c}-0.075 \\
{[0.002]}\end{array}$ & 101 & 0.844 & $\begin{array}{c}-0.009 \\
{[0.116]}\end{array}$ & $\begin{array}{c}-0.012 \\
{[0.049]}\end{array}$ & $\begin{array}{c}0.071 \\
{[0.002]}\end{array}$ & $\begin{array}{c}0.062 \\
{[0.007]}\end{array}$ \\
\hline $\begin{array}{l}\text { Compustat } \\
\text { population }\end{array}$ & 35,683 & $\begin{array}{c}-0.002 \\
(0.000)\end{array}$ & $\begin{array}{c}0.000 \\
(0.826)\end{array}$ & 4,966 & 0.822 & $\begin{array}{c}0.003 \\
(0.015)\end{array}$ & $\begin{array}{c}0.005 \\
(0.001)\end{array}$ & $\begin{array}{c}0.005 \\
{[0.000]}\end{array}$ & $\begin{array}{c}0.004 \\
{[0.002]}\end{array}$ \\
\hline Difference & & $\begin{array}{c}-0.078 \\
{[0.001]}\end{array}$ & $\begin{array}{c}-0.075 \\
{[0.001]}\end{array}$ & & $\begin{array}{l}-0.022 \\
(0.509\end{array}$ & $\begin{array}{c}-0.012 \\
{[0.058]}\end{array}$ & $\begin{array}{c}-0.017 \\
{[0.013]}\end{array}$ & & \\
\hline
\end{tabular}


Table 4

Average abnormal current accruals in the year immediately prior to the MBO announcement by industry and level of external financing

External financing is deemed low (high) if total external financing (scaled by total firm value at the beginning of the fiscal period) is the bottom (top) quartile of the external financing distribution. We do not report results for the middle quartiles. Discretionary accrual is as defined in Table 2. The number of observations is reported in brackets. $++/+$ indicate that the difference between the high external financing group and the low external financing group is significant at the $5 \% / 10 \%$ level in a one-tail test.

\begin{tabular}{|c|c|c|c|c|c|c|}
\hline \multirow[t]{2}{*}{$\begin{array}{l}\text { Industrial sector } \\
\text { (Two-digit SIC code) }\end{array}$} & \multicolumn{2}{|c|}{$\begin{array}{c}\text { Full } \\
\text { Sample }\end{array}$} & \multicolumn{2}{|c|}{$\begin{array}{c}\text { Low } \\
\text { external financing }\end{array}$} & \multicolumn{2}{|c|}{$\begin{array}{c}\text { High } \\
\text { external financing }\end{array}$} \\
\hline & $\begin{array}{l}\text { Unmatched } \\
A B C A\end{array}$ & $\begin{array}{c}\text { Matched } \\
\text { ABCA }\end{array}$ & $\begin{array}{l}\text { Unmatched } \\
\qquad A B C A\end{array}$ & $\begin{array}{c}\text { Matched } \\
\text { ABCA }\end{array}$ & $\begin{array}{l}\text { Unmatched } \\
\qquad A B C A\end{array}$ & $\begin{array}{c}\text { Matched } \\
\text { ABCA }\end{array}$ \\
\hline $\begin{array}{l}\text { Manufacturing } \\
(20-39)\end{array}$ & $\begin{array}{c}-0.027 \\
\{59\}\end{array}$ & $\begin{array}{c}-0.029 \\
\{59\}\end{array}$ & $\begin{array}{l}-0.051 \\
\{12\}\end{array}$ & $\begin{array}{l}-0.056 \\
\{12\}\end{array}$ & $\begin{array}{c}-0.008^{+} \\
\{12\}\end{array}$ & $\begin{array}{c}-0.008^{++} \\
\{12\}\end{array}$ \\
\hline $\begin{array}{l}\text { Merchandising } \\
(50-59)\end{array}$ & $\begin{array}{c}-0.013 \\
\{33\}\end{array}$ & $\begin{array}{c}-0.016 \\
\{33\}\end{array}$ & $\begin{array}{c}-0.044 \\
\{5\}\end{array}$ & $\begin{array}{c}-0.055 \\
\{5\}\end{array}$ & $\begin{array}{l}0.011 \\
\{11\}\end{array}$ & $\begin{array}{c}0.007 \\
\{11\}\end{array}$ \\
\hline $\begin{array}{l}\text { Services } \\
(48,49,60-67,70-87)\end{array}$ & $\begin{array}{c}-0.023 \\
\{41\}\end{array}$ & $\begin{array}{c}-0.022 \\
\{41\}\end{array}$ & $\begin{array}{c}-0.053 \\
\{16\}\end{array}$ & $\begin{array}{c}-0.041 \\
\{16\}\end{array}$ & $\begin{array}{c}0.034^{++} \\
\{10\}\end{array}$ & $\begin{array}{c}0.023^{++} \\
\{10\}\end{array}$ \\
\hline $\begin{array}{l}\text { Other industries } \\
(13,17,40,42,45)\end{array}$ & $\begin{array}{c}0.001 \\
\{5\}\end{array}$ & $\begin{array}{c}0.004 \\
\{5\}\end{array}$ & $\begin{array}{c}-0.061 \\
\{1\}\end{array}$ & $\begin{array}{c}-0.055 \\
\{1\}\end{array}$ & $\begin{array}{c}0.071 \\
\{1\}\end{array}$ & $\begin{array}{c}0.097 \\
\{1\}\end{array}$ \\
\hline
\end{tabular}


Table 5

Association between external financing and abnormal current accruals measured in the year immediately preceding the $\mathrm{MBO}$ year: Ordinary least square $(N=138)$

$$
\begin{array}{rlr}
A B C A_{i}= & \alpha_{1} S E F_{i}+\alpha_{2} S P P E_{i}+\alpha_{3} S E F_{i} * S P P E_{i}+\alpha_{4} C N T R_{i}+\alpha_{5} B M_{i}+\text { Year Fixed Effect }+\varepsilon_{i .} & \text { (Panel A) } \\
A B C A_{i}= & \alpha_{1} L O G E F_{i}+\alpha_{2} L O G P P E_{i}+\alpha_{3} L O G E F_{i} * L O G P P E_{i}+\alpha_{4} C N T R_{i}+\alpha_{5} B M_{i} \\
& + \text { Year Fixed Effect }+\varepsilon_{i}, & \text { (Panel B) }
\end{array}
$$

$A B C A$ is the abnormal current accrual for the fiscal year the immediately precede the MBO announcement; $S E F$ is total financing from external sources, which is scaled by total firm value in Panal A and is unscaled in Panal B; SPPE is the net beginning of property, plant, and equipment (PP\&E) scaled by total firm value; $C N T R$ is the proportion of the company controlled by the MBO group prior to the MBO [1 - ACQ]; $A C Q$ is the proportion of the company acquired in the MBO transaction; $B M$ is book value of equity divided by market value of equity at the beginning of the fiscal year; and the subscript $i$ stands for MBO $i$. Unexpected current accruals and abnormal current accruals are as defined in Table 2. Two-tail $p$-values are reported in parentheses and one-tail $p$-values are reported in brackets.

Panel A: External financing is scaled

\begin{tabular}{lcc}
\hline & $A B C A=$ Unmatched abnormal current & $A B C A=$ Matched abnormal current \\
& accruals & accruals \\
\hline $\boldsymbol{S E F}$ & $\mathbf{0 . 1 1 3}$ & $\mathbf{0 . 1 1 2}$ \\
& {$[\mathbf{0 . 0 0 0 ]}$} & {$[\mathbf{0 . 0 0 0}]$} \\
SPPE & 0.177 & 0.187 \\
& $(0.001)$ & $(0.000)$ \\
SEF $\boldsymbol{F}^{*}$ SPPE & $\mathbf{- . 1 9 5}$ & $\mathbf{- 0 . 2 1 2}$ \\
& {$[\mathbf{0 . 0 0 2}$} & {$[\mathbf{0 . 0 0 1}]$} \\
CNTR & 0.031 & 0.030 \\
& {$[0.159]$} & {$[0.160]$} \\
BM & -0.012 & -0.015 \\
& {$[0.078]$} & {$[0.033]$} \\
Year fixed effects & Yes & Yes \\
Adjusted $R^{2}$ & 0.253 & 0.254 \\
\hline
\end{tabular}

Panel B: External financing is unscaled

\begin{tabular}{lcc}
\hline & $A B C A=$ Unmatched abnormal current & $A B C A=$ Matched abnormal current \\
& accruals & accruals \\
\hline LOGEF & $\mathbf{0 . 0 2 5}$ & $\mathbf{0 . 0 2 4}$ \\
LOGPPE & {$[\mathbf{0 . 0 0 1}]$} & {$[\mathbf{0 . 0 0 3}]$} \\
& 0.016 & 0.016 \\
LOGEF ${ }^{*}$ LOGPP & $(0.107)$ & $(0.109)$ \\
& $\mathbf{- 0 . 0 0 4}$ & $\mathbf{- 0 . 0 0 4}$ \\
CNTR & {$[\mathbf{0 . 0 1 6}$} & {$[\mathbf{0 . 0 1 9}]$} \\
& 0.019 & 0.019 \\
BM & {$[0.272]$} & {$[0.265]$} \\
& -0.001 & -0.004 \\
Year Fixed Effect & {$[0.456]$} & {$[0.296]$} \\
Adjusted $R^{2}$ & Yes & Yes \\
\end{tabular}


Table 6

Association between external financing and abnormal current accruals: The first year prior to the MBO (Year 0) versus the second year prior to the MBO (Year-2): Ordinary least square $(N=108)$

$$
A B C A_{i}=\alpha_{1} S E F_{i}+\alpha_{2} S P P E_{i}+\alpha_{3} S E F_{i} * S P P E_{i}+\alpha_{4} C N T R_{i}+\alpha_{5} B M_{i}+\text { Year Fixed Effect }+\varepsilon_{i .}
$$

In Year 0, we measure all the variables over fiscal year ending within 1 to 12 months prior to the MBO announcement and, in Year-2, we measure all the variables over fiscal year ending within 25 to 36 months prior to the MBO announcement. We require that a firm have necessary observations in both Year 0 and Year-2. The variables are defined in Tables 2 and 5. Two-tail $p$-values are reported in parentheses and one-tail $p$-values are reported in brackets. We do not report the year intercepts.

\begin{tabular}{|c|c|c|c|c|}
\hline \multirow[t]{2}{*}{ Coefficient } & \multicolumn{2}{|c|}{$\begin{array}{c}A B C A=\text { Unmatched abnormal } \\
\text { current accruals }\end{array}$} & \multicolumn{2}{|c|}{$\begin{array}{c}A B C A=\text { Matched abnormal current } \\
\text { accruals }\end{array}$} \\
\hline & Year 0 & Year-2 & Year 0 & Year-2 \\
\hline$\overline{S E F}$ & $\begin{array}{c}\mathbf{0 . 1 0 0} \\
{[\mathbf{0 . 0 0 7}]}\end{array}$ & $\begin{array}{l}-0.004 \\
(0.916)\end{array}$ & $\begin{array}{c}0.128 \\
{[0.001]}\end{array}$ & $\begin{array}{r}-0.002 \\
(0.958)\end{array}$ \\
\hline$S P P E$ & $\begin{array}{c}0.154 \\
(0.010)\end{array}$ & $\begin{array}{c}0.010 \\
(0.882)\end{array}$ & $\begin{array}{c}0.193 \\
(0.002)\end{array}$ & $\begin{array}{c}0.021 \\
(0.740)\end{array}$ \\
\hline$S E F * S P P E$ & $\begin{array}{l}-0.179 \\
{[0.016]}\end{array}$ & $\begin{array}{l}-\mathbf{- 0 . 0 5 6} \\
(\mathbf{0 . 4 8 5})\end{array}$ & $\begin{array}{l}-0.239 \\
{[0.003]}\end{array}$ & $\begin{array}{r}-0.071 \\
(0.378)\end{array}$ \\
\hline CNTR & $\begin{array}{l}-0.009 \\
{[0.591]}\end{array}$ & $\begin{array}{l}-0.045 \\
(0.275)\end{array}$ & $\begin{array}{l}-0.005 \\
{[0.550]}\end{array}$ & $\begin{array}{l}-0.038 \\
(0.357)\end{array}$ \\
\hline$B M$ & $\begin{array}{l}-0.010 \\
{[0.136]}\end{array}$ & $\begin{array}{l}-0.010 \\
(0.600)\end{array}$ & $\begin{array}{l}-0.016 \\
{[0.040]}\end{array}$ & $\begin{array}{l}-0.009 \\
(0.658)\end{array}$ \\
\hline Year fixed effects & Yes & Yes & Yes & Yes \\
\hline Adjusted $R^{2}$ & 0.153 & 0.048 & 0.222 & 0.035 \\
\hline
\end{tabular}


Table 7

Effect of external financing on abnormal current accruals measured in the year immediately preceding the MBO year: Two-stage least square $(N=138)$

$$
\begin{aligned}
& S E F_{i}=\alpha_{1} A C Q_{i}+\alpha_{2} S_{C A S H}+\alpha_{3} C A P E X_{i}+\alpha_{4} L E V E R A G E_{i}+\alpha_{5} L_{A G R O A_{i}}+\alpha_{5} L_{O G V A L U E_{i}} \\
& + \text { Industry Fixed Effect }+ \text { Year Fixed Effect }+\varepsilon_{i} \\
& A B C A_{i}=\alpha_{1} P S E F_{i}+\alpha_{2} S P P E_{i}+\alpha_{3} P S E F_{i} * S P P E_{i}+\alpha_{4} C N T R_{i}+\alpha_{5} B M_{i}+\text { Year Fixed Effect } \\
& +\varepsilon_{i} \quad \text { (second stage) }
\end{aligned}
$$

$A C Q$ is the proportion of the company acquired in the MBO transaction, $S C A S H$ is cash balance scaled by total firm value at the beginning of the year prior to the $\mathrm{MBO}$ announcement, CAPEX is capital expenditures in the year prior to the MBO announcement scaled by beginning assets, LEVERAGE is total liabilities divided by total assets at the beginning of the year prior to the $\mathrm{MBO}$ announcement, LAGROA is return-on-assets for the year prior to the pre-MBO year, LOGVALUE is the logarithm of the firm value; and $P S E F$ is the predicted value of $S E F$ from the first-step regression. The other variables are defined as in Tables 2 and 5. Two-tail $p$-values are reported in parentheses and one-tail $p$-values are reported in brackets. We do not report the year intercepts.

Panel A: First-stage regression

\begin{tabular}{lcccccccr}
\hline & ACQ & SCASH & CAPEX & LEVERAGE & LAGROA & LOGVALUE & Fixed Effects & Adj. $R^{2}$ \\
\hline Coefficient & 0.650 & -0.346 & 1.003 & -0.317 & 0.613 & -0.038 & Yes & 0.855 \\
One-tail $p$-value & 0.000 & 0.010 & 0.010 & 0.008 & 0.013 & 0.052 & & \\
\hline
\end{tabular}

Panel B: Second-stage regression

\begin{tabular}{lcc}
\hline & $\begin{array}{c}\text { ABCA }=\text { Unmatched abnormal current } \\
\text { accruals }\end{array}$ & $\begin{array}{c}A B C A=\text { Matched abnormal current } \\
\text { accruals }\end{array}$ \\
\hline $\boldsymbol{P S E F}$ & $\mathbf{0 . 1 3 9}$ & $\mathbf{0 . 1 2 6}$ \\
SPPE & {$[\mathbf{0 . 0 0 2}]$} & {$[\mathbf{0 . 0 0 4}]$} \\
& 0.170 & 0.154 \\
$\boldsymbol{P S E F} \boldsymbol{F}^{*}$ SPPE & $(0.016)$ & $(0.027)$ \\
& $\mathbf{- 0 . 1 9 0}$ & $\mathbf{- 0 . 1 6 8}$ \\
CNTR & {$[\mathbf{0 . 0 2 3 ]}$} & {$[\mathbf{0 . 0 3 7 ]}$} \\
& 0.048 & 0.046 \\
BM & {$[0.115]$} & {$[0.122]$} \\
& -0.015 & -0.017 \\
Year Fixed Effect & {$[0.043]$} & {$[0.024]$} \\
Adjusted $R^{2}$ & Yes & Yes \\
\end{tabular}

